\title{
KOLABORASI PERGURUAN TINGGI DALAM MENINGKATKAN PEMBERDAYAAN MASYARAKAT DI KOTA PEKANBARU
}

\author{
Lusi Dwi Putri ${ }^{1)}$
}

1)Universitas Lancang Kuning Pekanbaru

e-mail :lusidwiputri@unilak.ac.id

\begin{abstract}
ABSTRAK
Program Kota Tanpa Kumuh (KOTAKU) di Kota Pekanbaru merupakan upaya strategis Direktorat Pengembangan Kawasan Permukiman, Ditjen Cipta Karya dalam rangka meningkatkan peran masyarakat dan memperkuat peran Pemda dalam penanganan kawasan kumuh dan mendukung gerakan 100-0-100 di perkotaan pada tahun 2016-2020. Tujuan program adalah menurunkan luas permukiman kumuh, tersusunnya rencana penanganan kumuh di tingkat kota dan di tingkat masyarakat serta meningkatnya penghasilan Masyarakat Berpenghasilan Rendah (MBR). Rencana penanganan kumuh di tingkat masyarakat disebut dengan Rencana Penataan Lingkungan Permukiman (RPLP). Dokumen RPLP ini merupakan dokumen perencanaan kelurahan yang disusun secara partisipatif. Keterbatasan sumber daya yang dimiliki masyarakat khususnya di Kelurahan Muara Fajar Kecamatan Rumbai membutuhkan peran serta dari perguruan tinggi sebagai bentuk pengamalan Tri Dharma Perguruan Tinggi. Tempat Pembuangan Sampah Akhir (TPA) Kota Pekanbaru berada di Kelurahan Muara Fajar. Masyarakat di Kelurahan Muara Fajar diberi pelatihan penyusunan dokumen RPLP dengan metode, Focuss Group Discussion (FGD), On the Job Training (OJT), diskusi dan tanya jawab. Hasil yang diperoleh adalah masyarakat belum sepenuhnya memahami tentang penyusunan RPLP ini, dari 20 (dua puluh) orang peserta dengan nilai 'Sangat Baik' 5\%, nilai 'Baik' $75 \%$ nilai 'Sedang' 20\% dan nilai 'Tidak Tampil' 0\%. Kegiatan pengabdian ini menghasilkan Dokumen RPLP sebagai outcome untuk penyusunan dokumen rencana penanganan kumuh di tingkat Kota.
\end{abstract}

Kata kunci : kawasan kumuh, kotaku, perencanaan partisipatif

\section{PENDAHULUAN}

\subsection{Analisa Situasi}

Kelurahan Muara Fajar merupakan kelurahan di Kota Pekanbaru yang menjadi lokasi Tempat Pembuangan Sampah Akhir (TPA) Kota Pekanbaru dengan luas area 7 (tujuh) hektar. Profil permukiman Kelurahan Muara Fajar dengan nilai di bawah $80 \%$ untuk kriteria fisik adalah pada indikator aksesibilitas lingkungan yaitu sebesar 53\% untuk kondisi jaringan jalan pada kawasan permukiman yang memiliki kualitas minimum memadai, saluran pembuangan air limbah rumah tangga yang terpisah dengan drainase lingkungan hanya sebesar $7 \%$. Masyarakat terlayani sarana air minum, mandi dan cuci sebesar $7 \%$. Pengelolaan persampahan untuk sampah domestik rumah tangga di kawasan permukiman terangkut ke TPS/TPA 2 (dua) kali seminggu sebesar 17\%. Kawasan permukiman memiliki prasarana/sarana proteksi kebakaran sebesar $0 \%$ (tidak ada). Untuk kriteria non fisik adalah mata pencaharian penduduk $57 \%$ perdagangan/jasa, penggunaan daya listrik 900 watt sebesar 68\% dan fasilitas pelayanan kesehatan sebesar $73 \%$ di puskesmas/pustu (KOTAKU, 2016).

Program Kota Tanpa Kumuh (KOTAKU) di Kota Pekanbaru merupakan upaya strategis Direktorat Pengembangan Kawasan Permukiman, Ditjen Cipta Karya dalam rangka meningkatkan peran masyarakat dan memperkuat peran Pemda dalam penanganan kawasan kumuh dan mendukung gerakan 100-0-100 di perkotaan pada tahun 2016-2020. Gerakan 100-0-100 adalah 100\% terpenuhinya akses air minum, 0\% wilayah kumuh perkotaan dan $100 \%$ terpenuhinya akses sanitasi. Tujuan program adalah menurunkan luas permukiman kumuh, tersusunnya rencana penanganan kumuh di tingkat kota dan di tingkat 
masyarakat serta meningkatnya penghasilan Masyarakat Berpenghasilan Rendah (MBR). Rencana penanganan kumuh di tingkat masyarakat disebut dengan Rencana Penataan Lingkungan Permukiman (RPLP). Dokumen RPLP ini merupakan dokumen perencanaan kelurahan yang disusun secara partisipatif dengan mewujudkan keterpaduan perencanaan tingkat kelurahan dan perencanaan tingkat kota dengan kedalaman perencanaan teknis.

Persoalan kumuh harus diselesaikan dengan segera agar tidak menimbulkan efek yang merugikan masyarakat dan sekitarnya. Penanganan tersebut harus dari berbagai sektor baik fisik maupun non-fisik melalui kolaborasi antar pemangku kepentingan dalam perencanaan yang terpadu karena persoalan kumuh ini tidak bisa diselesaikan sendirian oleh satu pihak. Keterbatasan sumber daya masyarakat di Kelurahan Muara Fajar membutuhkan adanya kolaborasi dari berbagai pihak agar dokumen perencanaan partisipatif ini bisa disusun dengan baik dan benar. Untuk itu pelaksana kegiatan pengabdian kepada masyarakat dari perguruan tinggi ingin memberikan peningkatan dan penguatan kapasitas kepada masyarakat melalui kegiatan pelatihan bagi tim perencanaan partisipatif tentang penyusunan RPLP Kelurahan Muara Fajar tahun 2016-2020.

\subsection{Tujuan Kegiatan}

Tujuan kegiatan pemberdayaan masyarakat melalui kegiatan pelatihan penyusunan dokumen RPLP adalah sebagai berikut :

a. Masyarakat memahami konsep dan tujuan penyusunan RPLP

b. Masyarakat memahami tahapan penyusunan RPLP

c. Masyarakat mampu mempraktikan penyusunan RPLP

d. Tersusunnya dokumen perencanaan partisipatif (RPLP)

\subsection{Khalayak Sasaran}

Peserta kegiatan pelatihan penyusunan RPLP ini adalah perwakilan dari seluruh tingkatan basis yang ada di Kelurahan yang tergabung dalam satu wadah bernama Tim Inti Perencanaan Partisipatif (TIPP) yang dibentuk dan disahkan oleh Kepala Kelurahan dengan beranggotakan dari unsur aparat kelurahan, relawan masyarakat dan unsur Lembaga Keswadayaan Masyarakat (LKM) di kelurahan Muara Fajar dengan jumlah 20 (dua puluh) orang.

\section{METODE}

Metode pelaksanaan yang digunakan dalam kegiatan ini adalah sebagai berikut :

\subsection{Metode Focus Group Discusion (FGD)}

Ada 3 (tiga) kapasitas yang hendak didorong dalam proses FGD agar materi/informasi yang disampaikan lebih terarah, yaitu mengerti, mau dan mampu. Pertama, mengerti, peserta harus mempunyai pengetahuan dan pemahaman tentang langkah-langkah penyusunan RPLP. Kedua, mau (motivasi), dalam menjalankan perannya setiap peserta harus mempunyai keyakinan dan motivasi bahwa mereka bagian dari pemecahan masalah di lingkungan mereka. Ketiga, mampu, setiap peserta harus mempunyai kemampuan membuat dan menyusun RPLP. Metodologi pendekatan adalah participatory andragogy, penyadaran kritis (menciptakan ruang untuk menganalisa secara bebas dan kritis), dialogis (komunikasi horisontal/partisipatif). Untuk keberlanjutan TIPP harus memiliki komitmen untuk melaksanakan program secara kontinu dan sebagai penggerak utama atau agent of change dalam masyarakat.

\subsection{Metode Pelatihan}

Terdapat dua metode pelatihan yang dapat digunakan oleh para mitra antara lain :

a. Belajar terstruktur meliputi sesi pertemuan kelas secara formal yang umumnya mencakup topik pelatihan serta pada saat FGD. 
b. Belajar secara mandiri memperbolehkan peserta pelatihan untuk belajar secara individual, sesuai dengan kecepatan belajarnya masing-masing. Peserta pelatihan disarankan untuk menemui instruktur pelatihan setiap saat untuk mengkonfirmasikan kemajuan dan mengatasi kesulitan belajar (khususnya pada saat OJT)

Adapun materi pelatihan yang diberikan pada kegiatan pelatihan ini adalah tentang penyusunan RPLP yaitu :

a. Syarat syarat penyusunan RPLP

b. Tujuan disusun RPLP

c. Keluaran dari penyusunan RPLP

d. Langkah-langkah penyusunan RPLP

Sarana dan prasarana yang harus ada dalam menunjang kegiatan pelatihan adalah sebagai berikut :

a. Menggunakan modul-modul pelatihan yang tepat guna untuk setiap kategori materi sebagai standarisasi pesan.

b. Menggunakan pemandu/nara sumber yang berkompeten di bidangnya.

c. Menggunakan media sebagai alat bantu pembelajaran.

\subsection{Pendampingan dan Evaluasi}

Evaluasi dilakukan melalui kegiatan Pre-Test, Post-Test dan evaluasi topik harian. Pre-Test dan Post-Test untuk mengukur tingkat penguasaan materi pelatihan. Evaluasi topik pembelajaran juga diberikan kepada peserta untuk mengukur pemahaman masing-masing peserta terhadap topik yang disampaikan oleh nara sumber. Pendampingan dilakukan agar peserta mampu menghasilkan dokumen RPLP.

\section{HASIL DAN PEMBAHASAN}

\subsection{Tempat dan Waktu Pelatihan}

Kegiatan pelatihan dilaksanakan di Sekretariat LKM Kelurahan Muara Fajar yang beralamat di Jalan Yos Sudarso KM. 22 Kelurahan Muara Fajar Kecamatan Rumbai Kota Pekanbaru. Lamanya waktu pelatihan adalah 4 (empat) hari.

\subsection{Peserta Pelatihan}

Peserta pelatihan berjumlah 20 (dua puluh) orang yang terdiri dari unsur anggota LKM, relawan dan perwakilan dari masing-masing basis $(\mathrm{RW})$.

\subsection{Pengamatan Peserta}

Dari proses pelatihan dinamika peserta berjalan dengan baik, terjadi komunikasi 2 (dua) arah yang bersifat dialogis dan kritis.

\subsection{Topik dan Pemandu}

Secara umum topik yang disampaikan pemandu sudah memenuhi kebutuhan pelatihan, namun untuk mengetahui seberapa jauh melihat topik dan pemandu dapat dilihat pada Evaluasi Topik dan Pemandu melalui beberapa aspek penilaian.

\subsection{Penilaian Peserta}

Untuk mengetahui sejauh mana pelaksanaan kegiatan pelatihan, telah dilakukan evaluasi penilaian peserta. Nilai tersebut dihitung dari pelaksanaan Pre Test dan Post Test dengan rumus sebagai berikut : 


$$
\text { Nilai }=\frac{\text { Jumlah soal bernilai benar }}{\text { Jumlah soal keseluruhan }} \times 100
$$

Contoh perhitungan, Ibu Darmainis adalah Koordinator LKM Fajar Gemilang, sebelum dilaksanakan pelatihan beliau mengikuti kegiatan Pre Test. Dari 11 (belas) soal yang diberikan ternyata ada 3 (tiga) soal yang dijawab benar sehingga dengan menggunakan rumus di atas maka nilai ibu darmainis adalah sebesar $27 \%$.

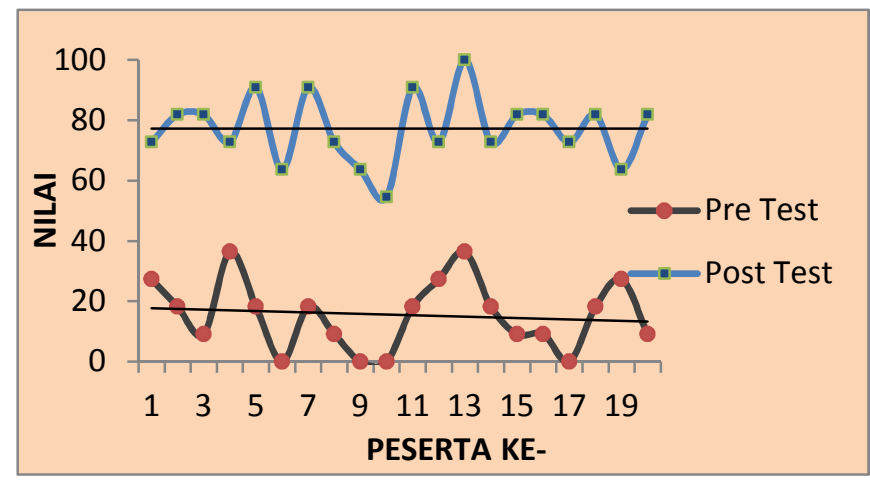

Gambar 1. Nilai Pre Test dan Post Test Peserta

\subsection{Pembahasan}

Dari hasil rekapitulasi diperoleh bahwa peningkatan pemahaman subtansi sebelum dan sesudah dilaksanakan sangat signifikan kenaikannya Dari grafik nilai Pre Test dan Post Test peserta pada gambar 1 diperoleh bahwa nilai yang diperoleh peserta ada yang lebih tinggi dari peserta lainnya begitu juga sebaliknya ada peserta yang lebih rendah dari peserta lainnya. Selama kegiatan berlangsung diamati bahwa peserta yang memiliki nilai yang lebih tinggi dari peserta lainnya dikarenakan peserta tersebut terlihat aktif selama kegiatan berlangsung seperti bertanya setiap tidak memahami substansi yang disampaikan oleh nara sumber serta memiliki wawasan yang luas terkait penataan kawasan. Peserta yang memiliki nilai lebih rendah dari peserta lainnya, berdasarkan hasil pengamatan pemandu/nara sumber mereka kurang aktif untuk bertanya, bahkan umpan balik yang diberikan oleh pemandu pun tidak direspon hal ini dikarenakan kemampuan masingmasing individu berbeda dalam memahami substansi yang diberikan melalui pelatihan yang hanya diberikan pada jangka waktu yang belum maksimal.

Dari hasil pelatihan yang diberikan diperoleh tingkat pemahaman masyarakat sebelumnya tentang penyusunan RPLP masih sangat rendah yaitu sebesar 15\% (lima belas persen). Peserta kurang memahami bahkan cendrung baru mengetahui tentang materi yang diberikan. Namun dengan adanya proses sharing antara peserta memudahkan pemahaman substansi yang diberikan. Setelah melalui kegiatan pelatihan ini kemampuan peserta menyerap substansi yang diberikan sebesar $77 \%$ (tujuh puluh tujuh persen) memperoleh nilai akhir Baik. Konsep pelatihan yang mengembangkan konsep komunikasi terbuka, peserta pelatihan bisa mempererat silaturahmi dalam rangka membuka jaringan informasi dan tukar pendapat terkait dengan masalah dan kendala serta upaya teknis atas keberhasilan perencanaan di kelurahan umumnya dan di tingkat basis khususnya. Dalam kegiatan pelatihan ini telah dihasilkan produk berupa dokumen RPLP berisikan rencana aksi penataan lingkungan permukiman Kelurahan Muara Fajar serta rencana investasi dan indikasi program untuk tahun 2016-2020. 


\section{SIMPULAN DAN SARAN \\ 4.1 Simpulan}

Dari semua tahapan kegiatan penelitian ini dapat diambil kesimpulan sebagai berikut :

a. Perlunya peran serta perguruan tinggi dalam meningkatakan kapasitas masyarakat sekitar dalam menyusun perencanaan partisipatif penataan lingkungan permukiman.

b. Meningkatnya kapasitas masyarakat dalam penyusunan RPLP, dimana tingkat pemahaman masyarakat terkait infrastruktur permukiman sebelum adanya pelatihan masih sangat rendah yaitu sebesar 15\% (lima belas persen) dan setelah mengikuti kegiatan pelatihan menjadi $77 \%$ (tujuh puluh tujuh persen).

c. Hasil akhir pelatihan untuk peserta dengan nilai 'Sangat Baik' sebesar $50 \%$, nilai 'Baik' sebesar 35\% nilai 'Sedang' 15\% dan nilai 'Tidak Tampil' sebesar 0\%.

d. Meningkatnya peran serta masyarakat dalam membangun kultur pembelajaran yang terorganisasi melalui komunitas belajar secara berkelanjutan melalui peran TIPP

e. Produk yang digunakan sebagai jembatan kemitraan adalah dokumen RPLP. Dalam kegiatan penelitian ini telah dihasilkan produk dari hasil OJT berupa dokumen RPLP yang nantinya merupakan outcome bagi masyarakat untuk penyusunan dokumen rencana penanganan kumuh di tingkat Kota.

\subsection{Saran}

Dari semua kegiatan pengabdian dapat disarankan sebagai berikut :

1. Diharapkan ada kontribusi lanjutan dari kalangan akademisi atau perguruan tinggi agar target utama yang diharapkan dapat terlaksana yaitu terpenuhi semua kebutuhan masyarakat untuk penataan lingkungan permukiman khususnya penataan kawasan kumuh di Perkotaan..

2. Ada sinergi dari semua pihak (pemerintah, swasta dan masyarakat) untuk mewujudkan infrastruktur permukiman yang layak secara berkelanjutan.

\section{REFERENCES}

Departemen Pekerjaan Umum Dirjen Cipta Karya, 2011, Strategi Pengembangan Kapasitas, PNPM Mandiri Perkotaan

https://www.researchgate.net/profile/Lusi_Dwi_Putri/publication/316701451_Kolaborasi_

Perguruan_Tinggi_Dalam_Perencanaan_Teknis_Infrastruktur_Permukiman_Bagi_M asyarakat_di_Kecamatan_Marpoyan_Damai_Kota_Pekanbaru/links/590ded2a0f7e9b 2863a466ec/Kolaborasi-Perguruan-Tinggi-Dalam-Perencanaan-Teknis-InfrastrukturPermukiman-Bagi-Masyarakat-di-Kecamatan-Marpoyan-Damai-Kota-Pekanbaru.pdf Putri.LD, Lubis.F, Soehardi.F. 2016, Kolaborasi Perguruan Tinggi dalam Perencanaan Teknis Infrastruktur Permukiman bagi Masyarakat di Kecamatan Marpoyan Damai Kota Pekanbaru. Seminar Nasional Universitas Pasir Pengaraian. 01 Agustus 2016, Pasir Pengaraian, Rokan Hulu.

Republik Indonesia, 2011, Undang-Undang No. 1/2011 tentang Perumahan dan Kawasan Permukiman, Lembaran Negara RI Tahun 2011, No 7, Sekretariat Negara RI

Satuan Kerja Pengembangan Kawasan Permukiman dan Penataan Bangunan (PKP2B) Provinsi Riau, 2015, Kebijakan Nasional Program Peningkatan Kualitas Permukiman Direktorat Cipta Karya, Satker PKP2B Riau

Sistem Informasi Manajemen Program Peningkatan Kualitas Kawasan Permukiman, 2016, Kelengkapan Data Lokasi Kumuh Baseline 100-0-100. Aviable from : http://sim.p2kp.org/p2kp/report/kelengkapan_data_kumuh.php?kode=14, Accesed : 2016, February 7

Tim Nasional Percepatan Penanggulangan Kemiskinan (TNP2K), 2012, Agenda Pembangunan Global Pasca 2015, Sekretariat Wakil Presiden RI 